during the deposit of our Eocene series differed widely at each period. Now my acquaintance with the Eocene formation, and with its Fauna in various ways, ${ }^{1}$ is somewhat more than Mr. Gardner gives me credit for; and I distinetly traverse his suggestion that the Fauna of the beds he names affords (when allowance is made for varying conditions of bottom and depth, and for the difficulty in making comparisons between faunas of which some are marine, some fluviomarine, and some fluviatile, as is the case with these beds) any indication whatever of a diversity of climate. Fortifying the opinion which I have formed from my own acquaintance with these beds, and with their Fauna, by that to the same purport of my father, who has made the study of the Tertiary Mollusca the occupation of the greater part of a long life, I contend that, so far as the past can be judged from what is known of the present, this fauna is of tropical character throughout. It was once thought that the mollusca of the Thanet sands indicated a colder climate than did those of the beds which succeed it, but the subsequent discovery of a Nautilus in these sands has made even that view difficult to be maintained. Moreover, not only do the Eocene beds of Western Europe present this character, but the close similarity between Eocene mollusca found in the Aral-sea region and those from the English and French beds indicates that this climate prevailed under nearly the same latitude as far, at least, as the meridian of $60^{\circ}$ East longitude.

I have trespassed thus much on your space, to vindicate the opposition which I offered to Mr. Gardner's hypothesis of oscillations of climate during the Eocene period; and I could pursue the subject further, as well as offer reasons for disagreeing from his alternative theory of the existence of a mean annual temperature, which permitted the growth of sub-tropical and more temperate forms side by side; but as he expresses his intention of not entering into any discussion with me, this would be undesirable, as I should be sorry to tempt him into any descent from the serene elevation on which he has placed himself.

I would, however, observe that, although the explanation which I offered as to the Hampshire Flora seemed to me the most obvious in that particular case, and although I do look upon both of Mr. Gardner's hypotheses as remote from the truth, I have nothing to say in opposition to Prof. Heer's view that difference of climate according to latitude did not; so far as it is evidenced by fossil vegetation, begin to show itself until late in the Mesozoic division of the Earth's history.

Searles V. Wood, Jun.

THE GONDWANA SERIES OF INDIA. ${ }^{2}$

SIR, - I have some remarks and corrigenda to add to my article on the Gondwana Series of India, ${ }^{3}$

First, as regards the classification of the whole area, as used in the above-mentioned paper, I have to state that it should be, properly, as
follows:

1 Amongst them, the original and first disinterment from the Hampshire cliff, in association with my father (now thirty-four years ago), of the remains of "Alligator, Turtle, and other Reptiles," to which Mr. Gardner in his paper refers. 2 The publication of this letter has been by an unfortunate oversight delayed a
month.-EDrT. Geol. MAG.

3 See Grox. MaG. Dec. II. Vol. III. p. 481. 
Gondwana Systex (not, as I wrote, "Gondwana Series").

a. Upper portion of the Gondwana System.

"Kachh-Jabalpúr Group" (not Kachh Series, as I wrote); "Rajmahal Group" (not, as I wrote, Rajmahal Series ), "etc.

b. Lower portion of the Gondroana System.

"Panchet Group"-_"Damuda Series" (not, as I wrote, Damuda Group, as it consists itself of sereral groups, as, Kamthi-Ranigunj group, Iron-shales, Barakur Group: this, however, only stratigraphieally).

"Talchir Group" (considered by me to be a lower portion of the Damuda Series).

In the chapter on the fossils of the Panchet Group (l. o. p. 486) I have to add that Prof. Huxley, although considering the vertebrate fossils as probably Triassic, found also some affinities with eertain Permian forms; but the closest connexion is still with the Triassic (?) South African reptilian remains. And here, in India, we have, as additional evidence, throughout a Triassic (Keuperic) Flora, which leaves little doubt that our Panchet Group, in comparison with already known formations, is to be considered as what is termed in Europe "Keuper." This, of course, is not intended to prove that both are contemporaneous. It proves only identity of forms, and therefore the some homotaxial position.

'I write this note especially because it should not seem that I have intentionally left out half of the arguments. I thought, however, to have said enough by referring to Prof. Huxley's important paper on the reptilian remains from the Panchet group, where he has himself so thoroughly discussed their affinities.

There are also some serious errata in the text, which should be corrected, namely :

On p. 485, line 5, for "with European Triassic forms," read "European Jurassic beds" (for the only beds in Kachh are Jurassic).

On p. 487 , line 12, omit "perhaps" (because there are certainly similar forms in Africa).

On p. 489, line 33, for "Pteroph. Carterianum," read "Pteroph. Morrisianum."

Calcutta, 14th Dec. 1876.

Dr. Ottokar Feistmanted, Geol. Survey of India.

\section{DR. FEISTMANTEL'S PAPER ON THE GONDWANA SERIES.}

Sir,-Even a scientific còntroversy, if prolonged, tends to become less amicable than it should be, and I shall therefore not attempt to reply at length to Dr. Feistmantel's remarks in his paper on the Gondwana Series of India, published in the Geological Magazine for November, 1876. I will only beg that any one who feels interested in the subject will do me the honour of consulting my original paper in the Records of the Geological Survey of India for 1876, pt. iii. pp. 79-85, because I do not think that a just idea of my views or of the objects of my paper will be derived from

1 This was the former collective name for the whole upper portion of the Gondwana system, as used by Dr. Oldham; but there are certaiuly several different groups. 